\title{
Adsorption of Fulvic Acid and Water Extractable Soil Organic Matter on Kaolinite and Muscovite
}

\author{
Ksenia Kolchanova, Inna Tolpeshta * (D) and Yulia Izosimova
}

check for

updates

Citation: Kolchanova, K.; Tolpeshta, I.; Izosimova, Y. Adsorption of Fulvic Acid and Water Extractable Soil Organic Matter on Kaolinite and Muscovite. Agronomy 2021, 11, 2420. https://doi.org/10.3390/ agronomy 11122420

Academic Editors: Evgeny Lodygin,

Evgeny Abakumov, Elena

Shamrikova and Guang-Wei Ding

Received: 13 October 2021

Accepted: 26 November 2021

Published: 27 November 2021

Publisher's Note: MDPI stays neutral with regard to jurisdictional claims in published maps and institutional affiliations.

Copyright: (c) 2021 by the authors. Licensee MDPI, Basel, Switzerland. This article is an open access article distributed under the terms and conditions of the Creative Commons Attribution (CC BY) license (https:// creativecommons.org/licenses/by/ $4.0 /)$.
Soil Science Faculty, Lomonosov Moscow State University, GSP-1, 1-12 Leninskie Gory, 119991 Moscow, Russia; kolchanovakseniia@yandex.ru (K.K.); izosimova.julya@yandex.ru (Y.I.)

* Correspondence: itolp@soil.msu.ru; Tel.: +7-4959395010

Abstract: The interaction of organic matter with mineral components of the solid phase of soils is the most important process that regulates the cycle and balance of carbon in the biosphere. The adsorption of humic acids on minerals is accompanied by their fractionation in size, composition, and amphiphilicity, thus decreasing their heterogeneity. Despite a strong interest in studying the regularities and mechanisms of the interaction between natural organic matter and layered aluminosilicates, it is necessary to take into account the natural diversity of soil organic matter, adsorption conditions, and mineral composition. This study was designed to investigate the adsorption regularities of fulvic acid (FA) and water-extractable organic matter (WEOM) isolated from horizon $\mathrm{H}$ of peaty-podzolic-gleyic soil on kaolinite and muscovite. Sorbates and sorbents were examined by the following methods: high-pressure size exclusion chromatography (HPSEC), high-performance liquid chromatography (HPLC), and potentiometric titration. The specific surface areas of the sorbents were determined by the sorption of $\mathrm{N}_{2}$ molecules. We found that hydrophobic components of FA and WEOM are mainly adsorbed on mineral surfaces. The adsorption of FA and WEOM on kaolinite and muscovite is followed by decreased hydrophobicity of organic matter and decreased heterogeneity of its amphiphilic properties in an equilibrium solution. At $\mathrm{pH}$ levels around 6, sorption of organic matter from FA solution containing 19\% and $81 \%$ hydrophilic and hydrophobic components, respectively, onto kaolinite and muscovite occurs mainly due to hydrophobic components. Hydrophobic interactions on siloxane surfaces are the main mechanism to fix FA on both minerals. Kaolinite adsorbs slightly more organic carbon per unit area than muscovite. The adsorption of WEOM from a solution with $41 \%$ hydrophilic and $59 \%$ hydrophobic components results not only from hydrophobic and hydrophilic components but also from hydrophobic and electrostatic interactions and depends on $\mathrm{pH}$. The most hydrophobic fractions of organic matter are adsorbed from the hydrophobic components on the surface of both minerals. Under conditions of the performed experiments at $\mathrm{pH}<5$, more WEOM is adsorbed on muscovite than on kaolinite.

Keywords: fulvic acids; clay minerals; adsorption; amphiphilicity

\section{Introduction}

The interaction of organic matter with mineral components of the solid phase of soils is the most important process that regulates the cycle and balance of carbon in the biosphere. Organic matter adsorbed on minerals becomes more resistant to microbial decomposition [1]. Adsorption prevents the leaching of organic matter from the soil profile. Attachment to mineral surfaces and increasing resistance to biodegradation promote organic matter accumulation in soils and ensure carbon sequestration [2-6]. Humic acids attached to the surface considerably modify the surface of minerals [7] and change their adsorption properties [7-10].

The adsorption of humic acids on minerals is accompanied by their fractionation in size [11], composition [12], and amphiphilicity [13], thus decreasing their heterogeneity. The experiments on the adsorption of humic acids and water-soluble organic matter show that 
larger molecules are adsorbed to a greater extent than smaller ones [11,14-16]. Humic acids with a large molecular size are adsorbed on the mineral surface, while fulvic acids with a smaller molecular size are adsorbed in the pores and reduce the mineral surface area [15]. Humic acids with a molecular weight of more than 100,000 Da are mainly represented by aliphatic compounds, while fractions of less than 30,000 Da mostly consist of aromatic components [11,17]. Aliphatic fractions of humic acid isolated from peat were revealed to have a higher affinity for the surface of kaolinite compared to aromatic fractions [13]. Wang and Xing established that aliphatic fractions of humic acid were predominantly adsorbed on both kaolinite and montmorillonite, while aromatic structures primarily remained in the solution. The humic acid adsorbed on both minerals was found to be more condensed than the original acid. The authors suggested that more condensed structures under low load could form on mineral surfaces as a result of strong surface interactions [12]. Experiments with water-soluble organic matter from lake water revealed that in a wide $\mathrm{pH}$ range, large hydrophobic molecules had a greater affinity for kaolinite, while small molecules high in carboxyl functional groups had little or no adsorption on the mineral [14]. Organic substances can be fixed on the mineral matrix of soil through various mechanisms, such as electrostatic interactions, hydrophobic interactions, ligand exchange, cation bridging, as well as hydrogen and van der Waals bonds [15,18-21].

High molecular weight compounds, hydrophobic fractions, and aromatic components can be selectively adsorbed on siloxane surfaces of kaolinite, while hydrophilic fractions with low molecular weight are adsorbed on the lateral surfaces of kaolinite crystallites [6,16].

The fulvic acid (FA) adsorption on T-basal surfaces occurs due to hydrogen bonds and hydrophobic interactions. Adsorption on the lateral surfaces of layered aluminosilicates and on the O-basal surfaces of kaolinite occurs mostly through ligand exchange and electrostatic interactions [21]. Ligand exchange was found to make a higher contribution to the adsorption of humic acids on kaolinite than on montmorillonite [18]. Using molecular-scale technologies of two-dimensional FTIR correlation spectroscopy and X-ray photoelectron spectroscopy, Chen et al. [22] showed that carboxyl and phenolic hydroxyls were adsorbed on the surface of kaolinite, forming $\mathrm{C}-\mathrm{O}-\mathrm{Al} / \mathrm{Si}$ bonds. The interaction of carboxyl groups with $\equiv \mathrm{AlOH}^{2+}$ kaolinite resulted from ligand exchange and/or electrostatic attraction, depending on $\mathrm{pH}$, and accounted for $13.9 \%, 7.76 \%$, and $0 \%$ of the total adsorption at $\mathrm{pH} 4.0$, 6.0, and 8.0, respectively [22].

The lower the $\mathrm{pH}$, the more humic acids can be adsorbed on $\mathrm{pH}$-dependent surfaces. The $\mathrm{pH}$ effect is more pronounced for kaolinite than for montmorillonite [21].

There are different points of view about the existence of a $\mathrm{pH}$-dependent charge on planar surfaces of kaolinite. Brady et al. studied kaolinite with a surface area of $10-11 \mathrm{~m}^{2} / \mathrm{g}$ using force electron microscopy. The authors found that the lateral surface area of kaolinite could be from 10 to $50 \%$ of the total surface area, depending on the size and shape of the crystallites. Based on the obtained data, the authors concluded that not the basal but mainly the lateral surfaces produced the electron density calculated from the proton adsorption isotherm [23]. When comparing the area of the lateral surfaces, cation exchange capacity (CEC) values, and the data of titrimetric analysis, Zhou and Gunter [24] concluded that the $\mathrm{pH}$-dependent charge of kaolinite could be found, not only on the lateral surfaces.

Gupta and Miller [25] studied the charge distribution on the surface of kaolinite using atomic force microscopy. The authors showed that at $\mathrm{pH}>4$, the siloxane surface was negatively charged, and the surface of the octahedral network was charged positively at $\mathrm{pH}<6$ and negatively at $\mathrm{pH}>8$. The results obtained suggest that the isoelectric point of the silicon-oxygen tetrahedral surface is at $\mathrm{pH}<4$, and the aluminum hydroxyl octahedral surface is in the $\mathrm{pH}$ range from 6 to 8 . Additionally, a $\mathrm{pH}$-dependent charge is present both on the siloxane surface and on the surface of the aluminum hydroxyl octahedra network [25].

Despite a strong interest in studying the regularities and mechanisms of the interaction between natural organic matter and layered aluminosilicates, it is necessary to take into 
account the natural diversity of soil organic matter, adsorption conditions, mineral composition, and properties of sorbents. Thus, further research is required to build predictive models for the fixation and mobilization of organic carbon in soils. There are many research papers devoted to the interaction of humic acids with the surface of kaolinite. However, the information on adsorption regularities of water-soluble organic matter and humic acids on illite and muscovite, the main mineral components of most soil types, is extremely limited.

The aim of this research was to study adsorption regularities of fulvic acid (FA) and water-extractable organic matter (WEOM) isolated from soil on kaolinite and muscovite.

\section{Materials and Methods}

\subsection{Sorbents}

For adsorption experiments, we used kaolinite from the Glukhovetskoe deposit (Ukraine) and muscovite (fractionated micromica (particle size $5 \mu \mathrm{m}$ ) of ZAO 'GEOKOM'). The mineral composition of clays was determined by X-ray diffractometry on a MiniFlex600 device (Rigaku, Tokyo, Japan) with a $\mathrm{CuK} \alpha$ and $\mathrm{K} \beta$ filter, a voltage of $30 \mathrm{kV}$, and a current of $15 \mathrm{~mA}$ and D/teX Ultra silicon strip detector.

Evaluation of the specific surface area was carried out using a Quadrasorb SI/Kr analyzer (Quantachrome Instruments, Boynton Beach, FL, USA). Adsorption was performed at the temperature of liquid nitrogen $(77.35 \mathrm{~K})$. Nitrogen with a purity of $99.999 \%$ served as an adsorbate. Helium grade $6.0(99.9999 \%)$ was used for the volume calibration of the measuring cells. The calculation was carried out by the BET multiple-point isotherm in the range of $\mathrm{P} / \mathrm{P} 0$ from 0.05 to 0.30 .

The $\mathrm{pH}$ of the point of zero charge $\left(\mathrm{pH}_{\mathrm{PZC}}\right)$ was determined by potentiometric titration. Thirty milliliters of $\mathrm{NaCl}$ solution with concentrations of $0.001,0.01$, and $0.1 \mathrm{~mol} / \mathrm{L}$ were poured onto $0.025 \mathrm{~g}$ of the mineral, and then stirred for $30 \mathrm{~min}$ and titrated with $0.1 \mathrm{M}$ $\mathrm{HCl}$ and $0.1 \mathrm{M} \mathrm{NaOH}$ in $\mathrm{N}_{2}$ atmosphere with an electrode DG111 on a Mettler Toledo DL 58 autotitrator (Mettler-Toledo AG, Schwerzenbach, Switzerland).

The $\mathrm{pH}$ of an aqueous mineral suspension was measured with a DG111 electrode on a Mettler Toledo DL58 device (Mettler-Toledo AG, Schwerzenbach, Switzerland) at a solid:liquid ratio of 1:50.

\subsection{Sorbates}

Fulvic acid (FA) was isolated from horizon $\mathrm{H}$ of peaty-podzolic-gleyic soil (Dystric Albic Gleyic Histic Retisol (Ruptic), WRB, 2014 [26]), sampled on the territory of the Central Forest State Nature Biosphere Reserve in the Tver region (the Russian Federation, $56028^{\prime} 57.1^{\prime \prime} \mathrm{N} ; 32,059^{\prime} 28.7^{\prime \prime}$ E) under the canopy of a blueberry-sphagnum spruce forest on a poorly drained watershed surface. The black smearing material of horizon $\mathrm{H}$ represents well-decomposed plant remains that lost their anatomical structure. Samples were taken from a depth of $15 \mathrm{~cm}$ at 10 locations over an area of about $20 \mathrm{~m}^{2}$, mixed, and dried at room temperature. The dried samples were crushed and sieved through a $1 \mathrm{~mm}$ sieve before extraction of FA and WEOM. To isolate FA, $500 \mathrm{~g}$ of the sample was poured with a $2.5 \mathrm{~L}$ $0.1 \mathrm{~N} \mathrm{NaOH}$ solution, shaken for an hour on a rotator $(230 \mathrm{rpm})$, and left for $23 \mathrm{~h}$. Then, the supernatant was separated by centrifugation. Centrifugation was carried out in a centrifuge (Eppendorf Centrifuge 5804, Germany) for $10 \mathrm{~min}$ at $4000 \mathrm{rpm}$. The described procedure was performed 4 times in succession. Then, the obtained alkaline extract was acidified with $\mathrm{HCl}$ to $\mathrm{pH} 2$ to precipitate humic acids and left for $24 \mathrm{~h}$. After that, FA dissolved in the supernatant was isolated by centrifugation ( $4000 \mathrm{rpm}, 10 \mathrm{~min}$ ) and purified by the Forsyth method [27] with additional HF treatment using the IHSS method (International Humic Substances Society) [28].

The $\mathrm{pKa}$ of functional groups was determined from the titration data of an aliquot of an FA aqueous solution acidified to $\mathrm{pH} 2$ by $0.1 \mathrm{~N} \mathrm{NaOH}$ in an $\mathrm{N}_{2}$ atmosphere with a DG111 electrode on a Mettler Toledo DL 58 autotitrator (Mettler-Toledo AG, Schwerzenbach, Switzerland) and calculated using Gran functions [29]. 
Water-soluble organic matter (WEOM) was extracted from the same soil horizon as FA. The sample was poured with distilled water in a solid:liquid ratio of 1:5 (600 g of the sample and $3 \mathrm{~L}$ of distilled water) and left for 3 days at a temperature of $20^{\circ} \mathrm{C}$. After incubation, the liquid phase was separated from the solid by filtration through a filter paper. The obtained aqueous extracts were passed through a membrane filter with a pore diameter of $0.45 \mu \mathrm{m}$ (OMNIPORE JHWP02500, Merck Millipore, Darmstadt, Germany) using a water jet pump.

In an aqueous solution of FA and WEOM, the $\mathrm{pH}$ was determined with an electrode (combined pH electrode LE438 IP 67) on an ion meter (F2-Standard (Mettler Toledo)). The total carbon content was measured using a liquid $\mathrm{CN}$ analyzer (High Temperature TOC/TNb Analyzer liquidTOC, Elementar Analysensysteme, GmbH, Langenselbold, Germany). Molecular weight distribution was determined with a BioRad BioLogic LP System chromatograph (USA) on Sephadex G-50 Superfine gel (Sweden). Amphiphilic distribution was determined using OCTYL-SEPHAROSE CL-4B gel (Sigma-Aldrich, St. Louis, MO, USA).

\subsection{Adsorption Experiment Technique}

In the adsorption experiment with FA, $0.3 \mathrm{~g}$ of each mineral was placed into a $50 \mathrm{~mL}$ plastic centrifuge tube and poured with $50 \mathrm{~mL}$ of FA solution at a concentration of $61.01 \mathrm{mg} / \mathrm{L}$ for $\mathrm{C}_{\text {org }}\left(10.17 \mathrm{mg} \mathrm{C}_{\text {org }}\right.$ per $1 \mathrm{~g}$ of mineral). The concentration of $\mathrm{C}_{\text {org }}$ in the FA solution was close to the concentration of $\mathrm{C}_{\text {org }}$ in soil solutions isolated from the $\mathrm{H}$ horizon of peaty-podzolic-gleyic soil (4.14-4.30 mmol/L) [30]. Then the suspension was shaken on a rotator for $24 \mathrm{~h}$ at $230 \mathrm{rpm}$ and filtered through a membrane filter with a pore size of $0.45 \mu \mathrm{m}$. In the resulting solution, the $\mathrm{pH}$ values, carbon content, molecular weight, and amphiphilic distributions were determined by the same methods as in the initial solution. The amount of adsorbed carbon was determined from the difference in the carbon concentration between the initial solution and the solution after the interaction of FA with the mineral.

The experiments were performed in duplicate. The experiments on the FA adsorption on kaolinite are hereinafter referred to as FAK1 and FAK2, and on muscovite as FAM1 and FAM2.

The adsorption experiment with WEOM was carried out in two variations as follows. One $\mathrm{g}$ of mineral placed in a $50 \mathrm{~mL}$ centrifuge tube was added to $50 \mathrm{~mL}$ of an aqueous WEOM extract with $C_{\text {org }}$ concentration of $337.06 \mathrm{mg} / \mathrm{L}\left(16.85 \mathrm{mg} \mathrm{C}_{\text {org }}\right.$ per $1 \mathrm{~g}$ of mineral). In the first variation of the experiment, as well as in the experiment with fulvic acid, the suspension was shaken on a rotator for $24 \mathrm{~h}$ at $230 \mathrm{rpm}$ and then filtered through a membrane filter with a pore diameter of $0.45 \mu \mathrm{m}$. In the resulting solution, the $\mathrm{pH}$ values, carbon content, molecular weight, and amphiphilic distributions were determined by the same methods as in the initial solution. The amount of adsorbed carbon was determined from the difference in carbon concentration before and after the interaction of WEOM with the mineral. In the second variation of the experiment with WEOM, the pH of the suspension was maintained at $4-4.5$ for $24 \mathrm{~h}$. These $\mathrm{pH}$ values are common to soil solutions from $\mathrm{H}$ horizons of peaty-podzolic-gleyic soil (4.14-4.30 $\mathrm{mmol} / \mathrm{L})$ [30].

The experiments were performed in duplicate. The experiments on the interaction of WEOM with kaolinite and muscovite without acidification of the suspension are hereinafter designated as WK1, WK2, WM1, and WM2, respectively. In the variation with acidified suspension, the experiments with kaolinite are designated as WK1a and WK2a, and with muscovite as WM1a and WM2a.

\section{Results}

Textural and surface properties of kaolinite and muscovite. Kaolinite was composed of 71\% particles with an average diameter of $<5$ microns. Muscovite was represented by larger fractions: $81 \%$ particles with an average diameter of 5-50 microns. The outer surface area 
of kaolinite was twice the surface area of muscovite. The volume and average pore size of kaolinite were larger than that of muscovite. Both minerals lacked micropores (Table 1).

Table 1. Textural and surface properties of kaolinite and muscovite.

\begin{tabular}{|c|c|c|c|c|c|c|c|}
\hline \multirow{2}{*}{ Mineral } & \multicolumn{2}{|c|}{ Particle Size Distribution } & \multirow{2}{*}{$\begin{array}{c}\text { Surface Area } \\
\mathrm{S}, \mathrm{m}^{2} / \mathrm{g} \\
(\mathrm{BET})\end{array}$} & \multirow{2}{*}{$\begin{array}{l}\text { Pore Volume/Average } \\
\text { Pore Size, nm (DET) }\end{array}$} & \multirow{2}{*}{$\begin{array}{l}\text { Micropore Volume, } \mathrm{cm}^{3} / \mathrm{g} \\
\text { (t-Plot Method, Halsey) }\end{array}$} & \multirow{2}{*}{$\mathrm{pH}$} & \multirow{2}{*}{$\mathrm{pH}_{\mathrm{PZC}}$} \\
\hline & $\mathrm{d}, \mu \mathrm{m}$ & $\%$ & & & & & \\
\hline \multirow{5}{*}{ Kaolinite } & $<1$ & 22.3 & \multirow{5}{*}{12.2} & \multirow{5}{*}{$0.066 / 29.4$} & \multirow{5}{*}{0} & \multirow{5}{*}{8.4} & \multirow{5}{*}{7.2} \\
\hline & $1-5$ & 48.7 & & & & & \\
\hline & $5-10$ & 14.3 & & & & & \\
\hline & $10-50$ & 14.7 & & & & & \\
\hline & $50-250$ & 0 & & & & & \\
\hline \multirow{5}{*}{ Muscovite } & $<1$ & 2.1 & \multirow{5}{*}{6.4} & \multirow{5}{*}{$0.027 / 7.0$} & \multirow{5}{*}{0} & \multirow{5}{*}{7.7} & \multirow{5}{*}{8.1} \\
\hline & $1-5$ & 12.8 & & & & & \\
\hline & $5-10$ & 29.9 & & & & & \\
\hline & $10-50$ & 51.2 & & & & & \\
\hline & $50-250$ & 4.0 & & & & & \\
\hline
\end{tabular}

The $\mathrm{pH}_{\mathrm{PZC}}$ of kaolinite was 7.2 units, and that of muscovite was 8.1 .

X-ray diffraction (XRD) analysis revealed that kaolinite contains minor admixtures of muscovite and quartz, yet quartz was not detected in the muscovite sample (Figure 1).

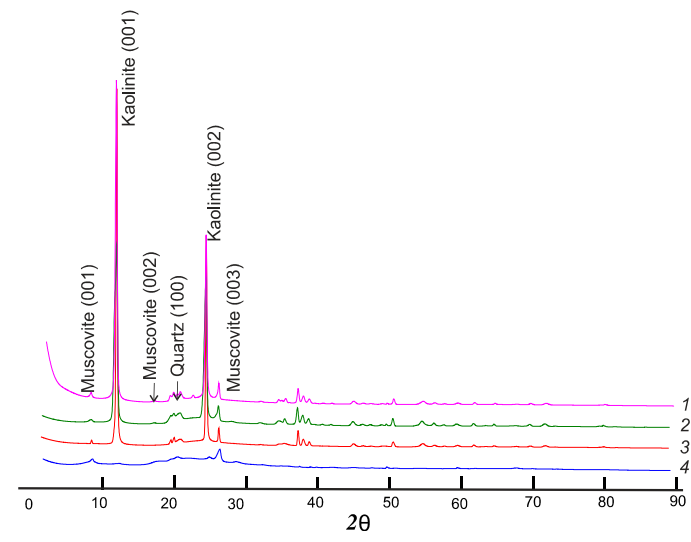

(A)

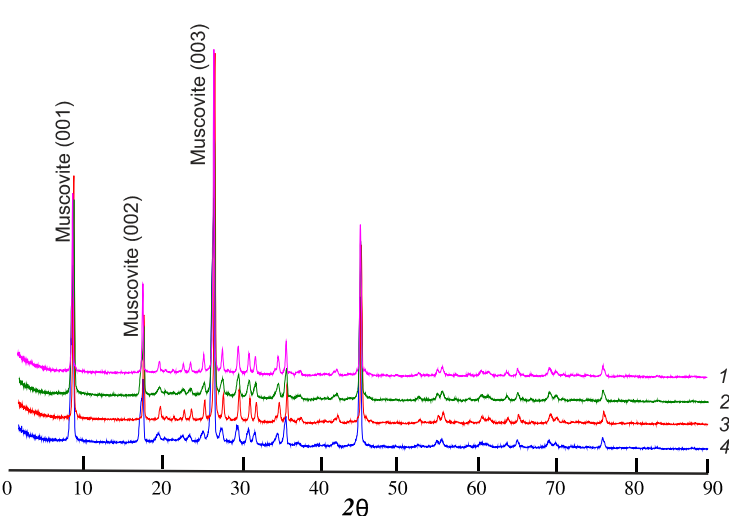

(B)

Figure 1. X-ray diffraction (XRD) patterns for kaolinite (A) and muscovite (B). The air-dried samples 1-4 were saturated with ethylene glycol and calcined at $350{ }^{\circ} \mathrm{C}$ and $550^{\circ} \mathrm{C}$, respectively.

Fulvic acid and WEOM properties. The aqueous solution of FA used for adsorption experiments contained a $61.01 \mathrm{mg} / \mathrm{L}$ concentration of $\mathrm{C}_{\text {org }}$ at $\mathrm{pH} 4.64$. FA contained functional groups with pKa1 4.1 and pKa2 5.7—-the latter significantly prevailed over the former. Titration data allowed us to distinguish another type of functional group with $\mathrm{pKa} 3 \approx 9$; however, we failed to determine their exact number.

The molecular weight distribution (MWD) curve displays a single peak corresponding to a molecular weight of 22,000 Da (Figure 2A).

FA has amphiphilic properties. The amphiphilic distribution curve shows that the hydrophilic fraction is represented by a broad peak of relatively low intensity, while the more hydrophobic components are represented by a group of partially overlapping peaks (Figure 2B). The hydrophilic peak accounts for 19\%, while the more hydrophobic components account for $81 \%$ of the total area of the peaks under the curve. The hydrophobicity coefficient of FA (hph), calculated as the ratio of the number of hydrophobic to hydrophilic components, is 4.26 units (Table 2). 


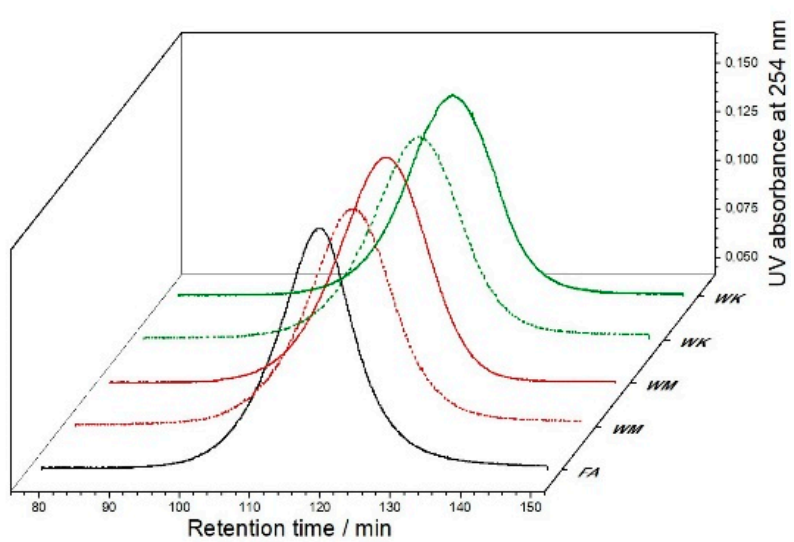

(A)

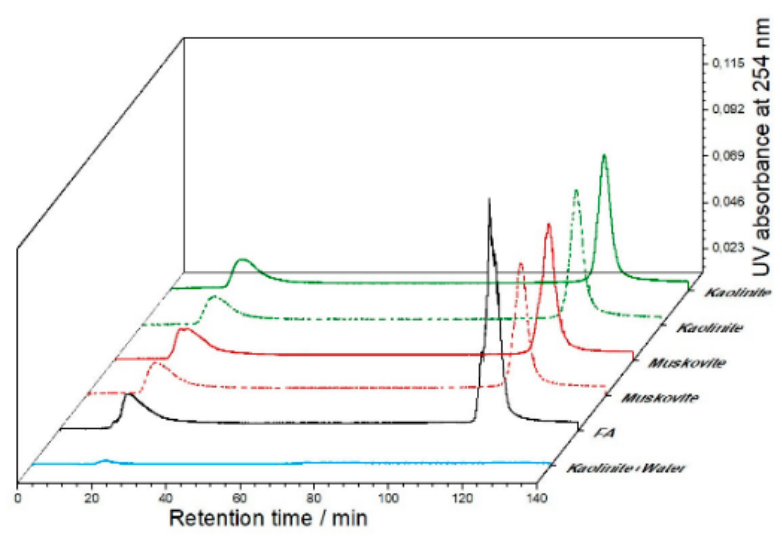

(B)

Figure 2. HPSEC chromatograms of FA (A) and amphiphilicity (B) before and after adsorption on kaolinite and muscovite.

Table 2. The FA solution properties before and after adsorption on minerals and the amount of $\mathrm{C}_{\text {org }}$ adsorbed.

\begin{tabular}{|c|c|c|c|c|c|c|}
\hline \multirow{2}{*}{ Sample } & \multirow{2}{*}{$\mathrm{pH}$} & \multirow{2}{*}{$\mathrm{C}_{\text {org }}, \mathrm{mg} / \mathrm{L}$} & \multirow{2}{*}{ Hydrophilic Fraction, \% } & \multirow{2}{*}{ Hydrophobic Fraction, \% } & \multirow{2}{*}{ hph } & \multirow{2}{*}{$\begin{array}{c}\text { C }_{\text {org }} \text { Adsorbed } \\
\mathrm{mg} / \mathrm{g}\end{array}$} \\
\hline & & & & & & \\
\hline FA & 4.64 & 61.01 & 24 & 76 & 4.20 & - \\
\hline FAK1 & 6.14 & 54.20 & 31 & 69 & 2.21 & 1.14 \\
\hline FAK2 & 5.99 & 52.71 & 31 & 69 & 2.22 & 1.38 \\
\hline FAM1 & 6.21 & 58.52 & 36 & 64 & 1.80 & 0.42 \\
\hline FAM2 & 6.25 & 58.69 & 35 & 65 & 1.83 & 0.39 \\
\hline
\end{tabular}

The water extract from the $\mathrm{H}$ horizon had an acidic reaction of the medium ( $\mathrm{pH} 4.58)$, where the concentration of $\mathrm{C}_{\text {org }}$ was $337.06 \mathrm{mg} / \mathrm{L}$. The molecular weight distribution is represented by one well-pronounced peak corresponding to a molecular weight of 21,000 Da (Figure 3A). According to the amphiphilic distribution curve, hydrophilic components are represented by a narrow peak and hydrophobic ones by three partially overlapping peaks (Figure 3B). Hydrophobic components prevailed over hydrophilic ones both in the water extract from the $\mathrm{H}$ horizon and in the FA solution; however, the WEOM hydrophobicity coefficient is less than that of FA and is equal to 1.43 units (Table 3). The close similarity of WEOM and FA molecular sizes indicates that WEOM components are mainly represented by FA.

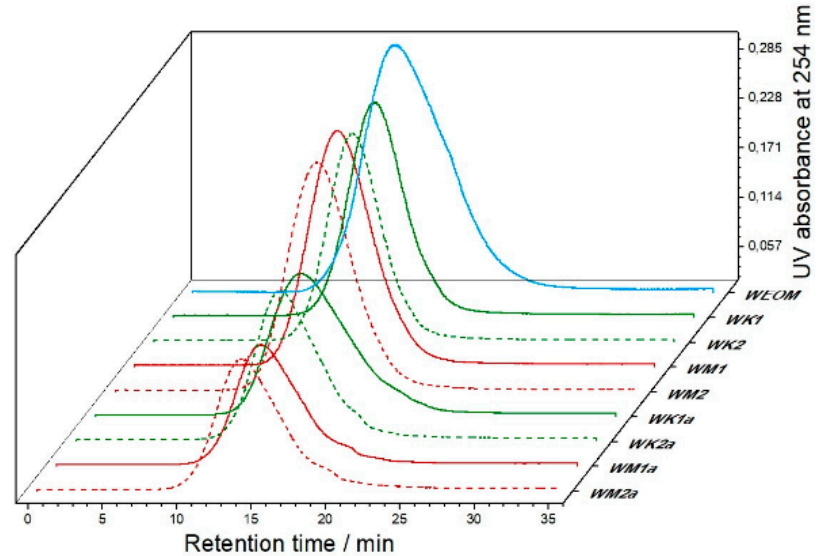

(A)

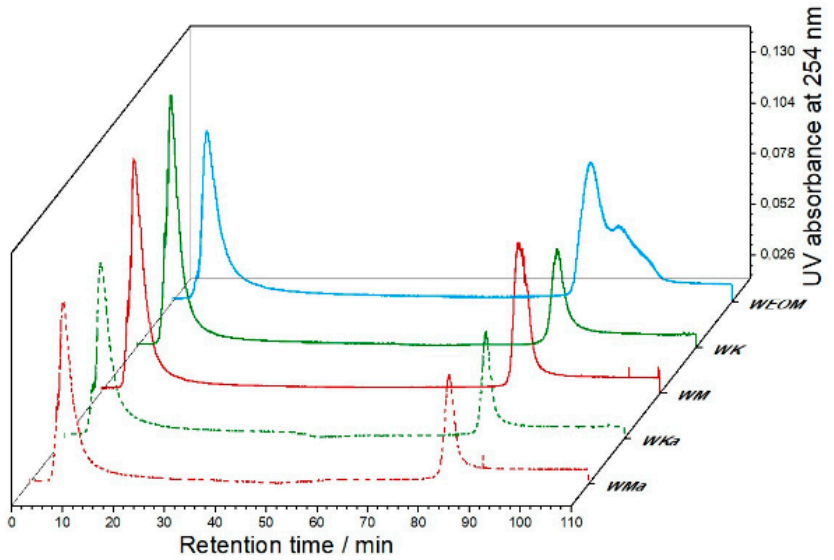

(B)

Figure 3. HPSEC chromatograms of WEOM (A) and amphiphilicity (B) before and after adsorption on kaolinite and muscovite. 
Table 3. WEOM properties before and after adsorption on minerals and the amount of $\mathrm{C}_{\text {org }}$ adsorbed.

\begin{tabular}{|c|c|c|c|c|c|c|}
\hline \multirow{2}{*}{ Sample } & \multirow{2}{*}{$\mathrm{pH}$} & \multirow{2}{*}{$\mathrm{C}_{\text {org }}, \mathrm{mg} / \mathrm{L}$} & \multirow{2}{*}{ Hydrophilic Fraction, \% } & \multirow{2}{*}{ Hydrophobic Fraction, \% } & \multirow{2}{*}{ hph } & \multirow{2}{*}{$\begin{array}{c}\text { Corg Adsorbed } \\
\mathrm{mg} / \mathrm{g}\end{array}$} \\
\hline & & & & & & \\
\hline WEOM & 4.58 & 337.06 & 41 & 59 & 1.43 & - \\
\hline WK1 & 4.69 & 306.36 & 70 & 30 & 0.43 & 1.38 \\
\hline WK2 & 4.74 & 304.86 & 69 & 31 & 0.44 & 1.45 \\
\hline WK1a & 4.07 & 281.86 & 68 & 32 & 0.47 & 4.46 \\
\hline WK2a & 4.04 & 279.16 & 68 & 32 & 0.47 & 5.44 \\
\hline WM1 & 4.90 & 307.61 & 67 & 33 & 0.49 & 1.33 \\
\hline WM2 & 4.97 & 310.36 & 66 & 34 & 0.51 & 1.20 \\
\hline WM1a & 4.38 & 268.36 & 68 & 32 & 0.47 & 3.19 \\
\hline WM2a & 4.34 & 269.73 & 68 & 32 & 0.47 & 3.12 \\
\hline
\end{tabular}

\section{WEOM and FA Adsorption}

As a result of the interaction between minerals and the FA solution, the $\mathrm{pH}$ of the equilibrium solution increased by two units compared to the initial value (Table 2).

The interaction with minerals resulted in the decrease of $C_{\text {org }}$ concentration in the FA solution. A greater reduction of $C_{\text {org }}$ concentration in the solution occurred after the adsorption on kaolinite in contrast with muscovite.

After the adsorption on minerals, HPSEC chromatograms of FA remained almost unchanged, while significant changes occurred on the amphiphilic distribution curve. The area of the peak corresponding to hydrophilic components after the adsorption of FA did not change, while the area under the curve corresponding to the site of hydrophobic compounds decreased, primarily due to the predominant adsorption of less hydrophobic components (Figure 2B). The adsorption led to the decreased proportion of hydrophobic components of FA and to the increased proportion of hydrophilic ones. The hydrophobic components were adsorbed mostly on the surface of kaolinite in comparison with muscovite. The hph coefficient of FA after the adsorption on kaolinite and muscovite decreased by 2.1 and 2.3 , respectively (Table 2 ).

After adsorption on kaolinite and muscovite, the $\mathrm{pH}$ of WEOM increased on average by 0.1 and 0.2 units, respectively, in the variation of the experiment without acidification (Table 3), which is significantly less than the change in $\mathrm{pH}$ observed after FA adsorption on minerals.

Like FA, WEOM was adsorbed on both minerals. More organic matter was adsorbed in the experiment with acidification than in the one without acidification.

In both variations of the experiment, the concentration of $C_{\text {org }}$ in equilibrium solutions after interaction with minerals proved to be quite similar in the experiments with both kaolinite and muscovite (Table 3).

As a result of the interaction of WEOM with kaolinite and muscovite, we did not observe noticeable changes in the size of the particles remaining in the solution after adsorption (Figure $3 \mathrm{~A}$ ).

There was a marked decrease in the WEOM hydrophobicity due to a reduced $\mathrm{C}_{\text {org }}$ after the interaction with minerals. In both variations of the experiment, the proportion of hydrophobic components in the solution before adsorption decreased from $59 \%$ to $30-32 \%$ after adsorption on kaolinite and to $32-34 \%$ after adsorption on muscovite, respectively (Table 3). The decrease in hydrophobicity resulted from the adsorption of the most hydrophobic components (Figure 3B).

\section{Discussion}

Acidity neutralization of FA and WEOM solutions. The increased equilibrium $\mathrm{pH}$ in the experiments with FA and WEOM without acidification compared to the $\mathrm{pH}$ of the initial solutions can be explained by the buffer properties of clay minerals. The suspension $\mathrm{pH}$ for kaolinite and muscovite in distilled water was 8.4 and 7.7, respectively (Table 1). Despite the narrower mineral:solution ratio in the experiments with WEOM, we observed 
a lower increase in the $\mathrm{pH}$ of the initial solution than in the experiments with FA. This can be explained by two factors: slightly higher $\mathrm{C}_{\text {org }}$ load in the WEOM experiments and higher acidity of WEOM organic matter than FA. The FA solution was dominated by $\mathrm{pKa}$ 5.7 functional groups. According to the data of Karavanova et al. [31], the pKa of acid components in soil solutions isolated from the $\mathrm{H}$ horizon of peaty-podzolic-gleyic soil vary from 5.15 to 5.36 units.

Regularities of FA adsorption. For these experiments, we used kaolinite and muscovite of different dispersion degrees. Moreover, both of these minerals had a rigid crystal lattice and showed little or no adsorption of organic matter under the performed experiments. Thus, it is reasonable to compare the adsorption capacity of minerals in terms of the amount of adsorbed $\mathrm{C}_{\text {org }}$ per unit surface area.

As a result of adsorption on both kaolinite and muscovite, size fractionation of FA components did not occur (Figure 2A). The particle size was similar to the pore size of both minerals [32,33].

Hydrophobic components were predominantly adsorbed on both kaolinite and muscovite. Therefore, it can be assumed that the main mechanism of FA fixation on both minerals is hydrophobic interactions. Hydrophobic interactions on kaolinite and muscovite occur on siloxane surfaces and do not depend on $\mathrm{pH}$. In terms of per unit area, kaolinite adsorbs slightly more $\mathrm{C}_{\text {org }}$ than muscovite at similar $\mathrm{pH}$ values (Table 2, Figure 4a). This tendency can be explained by the higher constant charge of muscovite, compared to kaolinite, which spreads onto siloxane surfaces [34]. Increasing charge causes decreased surface hydrophobicity, leading to inhibition of hydrophobic interactions.

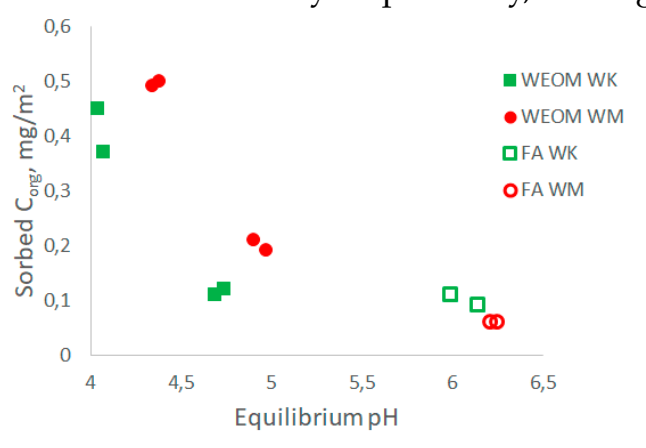

(a)

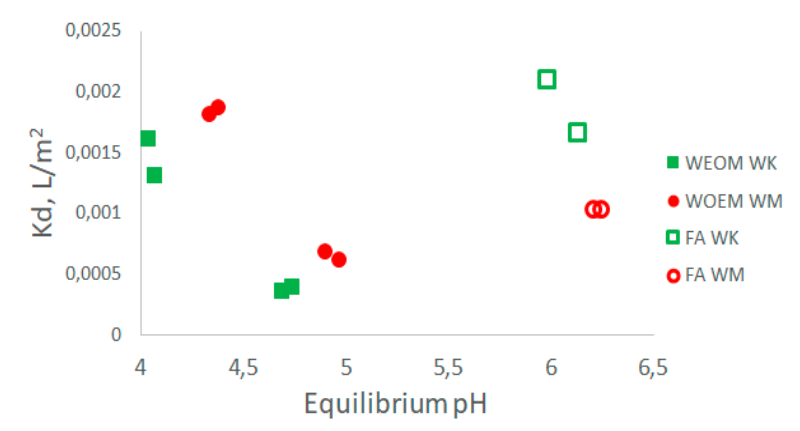

(b)

Figure 4. The dependence of adsorbed $\mathrm{C}_{\mathrm{org}}(\mathbf{a})$ and $\mathrm{Kd}(\mathbf{b})$ on equilibrium $\mathrm{pH}$.

The distribution coefficients of Kd were a little higher upon adsorption on kaolinite than on muscovite (Figure $4 \mathrm{~b}$ ), which may indicate stronger hydrophobic interactions of FA with the kaolinite surface as compared to the muscovite surface.

According to the data of potentiometric kaolinite titration, $\mathrm{pH}_{\mathrm{PZC}}$ is approximately 7 (Table 1), which greatly exceeds the range of $\mathrm{pH}_{\mathrm{PZC}}$ of kaolinite from 2.7 to $\approx 5.7[14,24,35]$. Kriaa et al. [36] report higher $\mathrm{pH}_{\mathrm{PZC}}$ from 6.5 to 7.8 units for kaolinite from the deposits of Tunisia. As will be shown below, the kaolinite used in this study contains a minute amount of muscovite, which is likely to increase the $\mathrm{pH}_{\mathrm{PZC}}$.

The obtained value lies within the range of $\mathrm{pH}_{\mathrm{PZC}}$ from 7.5-8.5 for muscovite and illite, according to the literature $[37,38]$.

As shown by Huertas et al. [39], neutral aluminol and silanol groups prevail on the surface of kaolinite with $\mathrm{pH}_{\mathrm{PZC}} \approx 5.5$ within $\mathrm{pH}$ from 4.5 to 8 . The authors calculated that weakly acidic side aluminol groups were completely protonated at $\mathrm{pH} \leq 3$, and hydroxyls on the basal surface were positively charged only at $\mathrm{pH}<3$ [39]. Liu et al. [40] showed that silanol $\equiv \mathrm{Si}-\mathrm{OH}$ and aluminol $\equiv \mathrm{Al}-\mathrm{OH}_{2} \mathrm{OH}$ groups had pKa 6.9 and pKa 5.7, respectively.

In this experiment, we used kaolinite with a higher $\mathrm{pH}_{\mathrm{PZC}}$ than most kaolinite considered in the literature. Therefore, aluminol groups could be partially protonated at $\mathrm{pH} \approx 6$. Gupta and Miller [25] demonstrate that the isoelectric point of the alumina hydroxyl octa- 
hedra surface is within the $\mathrm{pH}$ range from 6 to 8 . The FA solution is dominated by $\mathrm{pK}_{2}$ 5.7 acid groups close to the $\mathrm{pH}$ of equilibrium solutions. Consequently, approximately $50 \%$ of the $\mathrm{pK}_{2}$ functional groups were dissociated in the solution. Therefore, at least electrostatic interactions between the hydrophilic components of FA and the lateral surfaces of kaolinite or even protonated $\mathrm{OH}$-groups on the aluminum hydroxyl octahedra surface can be possible in this experiment. However, the amphiphilic distribution curves do not display adsorption of the hydrophilic fraction. This might be due to the fact that hydrophobic components significantly prevail over hydrophilic ones in the FA solution used for the experiment (Table 2).

The $\mathrm{pH}_{\mathrm{PZC}}$ of muscovite is higher than that of kaolinite. Aluminol groups in muscovite are characterized by slightly lower pKa1 values than in kaolinite and vary from 3.9 to 5.52 units [37,41]. The $\mathrm{pH}_{\text {PZC }}$ of the lateral surfaces of muscovite is $7.5 \pm 0.5$ [38]. Therefore, the adsorption of the hydrophilic fraction on the muscovite surface is possible but was not revealed in this experiment.

The pore size in both kaolinite and muscovite is larger than the average size of molecules in the FA solution (Table 1). Thus, the pore size does not affect the regularities of FA adsorption under the conditions of the given experiments.

Figure 2B shows that less hydrophobic components of the hydrophobic fraction are adsorbed on both minerals. To explain this fact, further research is required, including the determination of hydrophobic fraction composition.

Regularities of WEOM adsorption. Hydrophobic components prevail in WEOM, but their share is slightly higher than that of hydrophilic components (Table 3). In the experiment without acidification, the most hydrophobic WEOMs are adsorbed on both kaolinite and muscovite (Figure 3B).

The chromatograms of amphiphilic distribution in the variation of the experiment without acidification show that the intensity of the peak from the hydrophilic components increases after adsorption on minerals (Figure 3B), while the concentration of $\mathrm{C}_{\text {org }}$ decreases in equilibrium solution (Table 3). Thus, it can be concluded that WEOM is either transformed during adsorption, or that desorption of hydrophilic components occurs in the system within $24 \mathrm{~h}$. The experiments on the FA adsorption on muscovite at $\mathrm{pH} 3.7$ have revealed that the electron density of FA adsorbed on the mineral surface increases after three hours of interaction but decreases after $12 \mathrm{~h}$. The authors suggest that the change in the electron density may be caused by a low rate of FA adsorption or fractionation during adsorption, i.e., replacement of small FA molecules by larger ones [42]. However, in the variation of the experiment with acidification at $\mathrm{pH}$ of the equilibrium solution $\approx 4$, an increasing proportion of hydrophilic components was not observed. Further research is required to explain the results obtained.

The adsorption of WEOM increases with a decreased pH (Figure 4a). The abovementioned $\mathrm{pH}$-dependent surfaces of kaolinite and muscovite, and the fact that the $\mathrm{pKa}$ of functional groups of organic matter in solutions isolated from the $\mathrm{H}$ horizon of peatypodzolic-gleyic soil varies from 5.15 to 5.36 [31], allow us to conclude that at $\mathrm{pH}<5$, the adsorption of WEOM components, along with hydrophobic interactions, occurs due to electrostatic interactions on $\mathrm{pH}$-dependent surfaces. Such interactions can be carried out both due to deprotonated functional groups of organic matter and a positively charged $\mathrm{pH}$-dependent surface of minerals, as well as due to protonated functional groups of organic matter and a constant charge of the mineral surface. The latter mechanism explains the greater adsorption of WEOM on muscovite compared to kaolinite (Figure 4a). The Kd value also proved to be higher on muscovite than on kaolinite (Figure $4 \mathrm{~b}$ ).

In addition, under this study, we show that FA and WEOM can be fixed on the surface of kaolinite and muscovite via hydrogen bonding.

\section{Conclusions}

Our research showed that adsorption of FA and WEOM on kaolinite and muscovite is accompanied by decreasing hydrophobicity of organic matter and decreasing heterogeneity 
of its amphiphilic properties in an equilibrium solution. Under the experimental conditions at a $\mathrm{pH}$ of about 6 , the adsorption of organic matter from the FA solution containing $19 \%$ and $81 \%$ hydrophilic and hydrophobic components, respectively, on kaolinite and muscovite is performed predominantly due to hydrophobic components. Moreover, hydrophobic interactions occurring on siloxane surfaces are the main mechanism for the fixation of FA on both minerals. Kaolinite adsorbs slightly more $C_{\text {org }}$ per unit area than muscovite since a highly negative charge of muscovite prevents hydrophobic interactions on siloxane surfaces. $\mathrm{Kd}$ appeared to be slightly higher during adsorption on kaolinite than on muscovite. The adsorption of WEOM from the solution containing $41 \%$ hydrophilic and $59 \%$ hydrophobic components is performed by hydrophobic and hydrophilic compounds, as well as by hydrophobic and electrostatic interactions and depends on $\mathrm{pH}$. The most hydrophobic components are adsorbed on the surface of both minerals. Under the performed experiment at $\mathrm{pH}<5$, more WEOM is adsorbed on muscovite than on kaolinite. The $\mathrm{Kd}$ value is higher on muscovite than on kaolinite.

Author Contributions: Conceptualization, methodology, I.T.; data curation, formal analysis, investigation, K.K., Y.I.; writing—original draft preparation, K.K.; writing—review and editing, I.T., Y.I.; visualization, Y.I. All authors have read and agreed to the published version of the manuscript.

Funding: This research was supported by the Russian Foundation for Basic Research (project No 19-29-05028).

Institutional Review Board Statement: Not applicable.

Informed Consent Statement: Not applicable.

Data Availability Statement: Data may be available after request to the corresponding author.

Conflicts of Interest: The authors declare no conflict of interest.

\section{References}

1. Mikutta, R.; Mikutta, C.; Kalbitz, K.; Scheel, T.; Kaiser, K.; Jahn, R. Biodegradation of Forest Floor Organic Matter Bound to Minerals via Different Binding Mechanisms. Geochim. Cosmochim. Acta 2007, 71, 2569-2590. [CrossRef]

2. Kleber, M.; Eusterhues, K.; Keiluweit, M.; Mikutta, C.; Mikutta, R.; Nico, P.S. Mineral-Organic Associations: Formation, Properties, and Relevance in Soil Environments. Adv. Agron. 2015, 130, 1-140. [CrossRef]

3. Kögel-Knabner, I.; Guggenberger, G.; Kleber, M.; Kandeler, E.; Kalbitz, K.; Scheu, S.; Eusterhues, K.; Leinweber, P. Organo-Mineral Associations in Temperate Soils: Integrating Biology, Mineralogy, and Organic Matter Chemistry. J. Plant Nutr. Soil Sci. 2008, 171, 61-82. [CrossRef]

4. Jones, E.; Singh, B. Organo-Mineral Interactions in Contrasting Soils under Natural Vegetation. Front. Environ. Sci. 2014, 2, 2. [CrossRef]

5. Avneri-Katz, S.; Young, R.B.; McKenna, A.M.; Chen, H.; Corilo, Y.E.; Polubesova, T.; Borch, T.; Chefetz, B. Adsorptive Fractionation of Dissolved Organic Matter (DOM) by Mineral Soil: Macroscale Approach and Molecular Insight. Org. Geochem. 2017, 103, 113-124. [CrossRef]

6. Hong, H.; Chen, S.; Fang, Q.; Algeo, T.J.; Zhao, L. Adsorption of Organic Matter on Clay Minerals in the Dajiuhu Peat Soil Chronosequence, South China. Appl. Clay Sci. 2019, 178, 105125. [CrossRef]

7. Li, H.; Sheng, G.; Teppen, B.J.; Johnston, C.T.; Boyd, S.A. Sorption and Desorption of Pesticides by Clay Minerals and Humic Acid-Clay Complexes. Soil Sci. Soc. Am. J. 2003, 67, 122-131. [CrossRef]

8. Wang, S.; Hu, J.; Li, J.; Dong, Y. Influence of PH, Soil Humic/Fulvic Acid, Ionic Strength, Foreign Ions and Addition Sequences on Adsorption of $\mathrm{Pb}(\mathrm{II})$ onto GMZ Bentonite. J. Hazard. Mater. 2009, 167, 44-51. [CrossRef] [PubMed]

9. Wu, P.; Zhang, Q.; Dai, Y.; Zhu, N.; Dang, Z.; Li, P.; Wu, J.; Wang, X. Adsorption of Cu(II), Cd(II) and Cr(III) Ions from Aqueous Solutions on Humic Acid Modified Ca-Montmorillonite. Geoderma 2011, 164, 215-219. [CrossRef]

10. Izosimova, Y.; Tolpeshta, I.; Gurova, I.; Karpukhin, M.; Zakusin, S.; Krupskaya, V. Sorption of Cu ${ }^{2+}$ Ions by Bentonite Modified with Al Keggin Cations and Humic Acid in Solutions with PH 4.5. Minerals 2020, 10, 1121. [CrossRef]

11. El-sayed, M.E.A.; Khalaf, M.M.R.; Gibson, D.; Rice, J.A. Assessment of Clay Mineral Selectivity for Adsorption of Aliphatic/Aromatic Humic Acid Fraction. Chem. Geol. 2019, 511, 21-27. [CrossRef]

12. Wang, K.; Xing, B. Structural and Sorption Characteristics of Adsorbed Humic Acid on Clay Minerals. J. Environ. Qual. 2005, 34, 342-349. [CrossRef] [PubMed]

13. Ghosh, S.; Wang, Z.-Y.; Kang, S.; Bhowmik, P.C.; Xing, B.S. Sorption and Fractionation of a Peat Derived Humic Acid by Kaolinite, Montmorillonite, and Goethite. Pedosphere 2009, 19, 21-30. [CrossRef] 
14. Specht, C.H.; Kumke, M.U.; Frimmel, F.H. Characterization of NOM Adsorption to Clay Minerals by Size Exclusion Chromatography. Water Res. 2000, 34, 4063-4069. [CrossRef]

15. Zhang, L.; Luo, L.; Zhang, S. Integrated Investigations on the Adsorption Mechanisms of Fulvic and Humic Acids on Three Clay Minerals. Colloids Surf. A Physicochem. Eng. Asp. 2012, 406, 84-90. [CrossRef]

16. Chen, H.; Koopal, L.K.; Xu, J.; Wang, M.; Tan, W. Selective Adsorption of Soil Humic Acid on Binary Systems Containing Kaolinite and Goethite: Assessment of Sorbent Interactions. Eur. J. Soil Sci. 2019, 70, 1098-1107. [CrossRef]

17. Khalaf, M.; Kohl, S.D.; Klumpp, E.; Rice, J.A.; Tombácz, E. Comparison of Sorption Domains in Molecular Weight Fractions of a Soil Humic Acid Using Solid-State 19F NMR. Environ. Sci. Technol. 2003, 37, 2855-2860. [CrossRef]

18. Feng, X.; Simpson, A.J.; Simpson, M.J. Chemical and Mineralogical Controls on Humic Acid Sorption to Clay Mineral Surfaces. Org. Geochem. 2005, 36, 1553-1566. [CrossRef]

19. Lützow, M.v.; Kögel-Knabner, I.; Ekschmitt, K.; Matzner, E.; Guggenberger, G.; Marschner, B.; Flessa, H. Stabilization of Organic Matter in Temperate Soils: Mechanisms and Their Relevance under Different Soil Conditions-A Review. Eur. J. Soil Sci. 2006, 57, 426-445. [CrossRef]

20. Kleber, M.; Sollins, P.; Sutton, R. A Conceptual Model of Organo-Mineral Interactions in Soils: Self-Assembly of Organic Molecular Fragments into Zonal Structures on Mineral Surfaces. Biogeochemistry 2007, 85, 9-24. [CrossRef]

21. Chen, H.; Koopal, L.K.; Xiong, J.; Avena, M.; Tan, W. Mechanisms of Soil Humic Acid Adsorption onto Montmorillonite and Kaolinite. J. Colloid Interface Sci. 2017, 504, 457-467. [CrossRef]

22. Chen, H.; Li, Q.; Wang, M.; Ji, D.; Tan, W. XPS and Two-Dimensional FTIR Correlation Analysis on the Binding Characteristics of Humic Acid onto Kaolinite Surface. Sci. Total Environ. 2020, 724, 138154. [CrossRef] [PubMed]

23. Brady, P.V.; Cygan, R.T.; Nagy, K.L. Molecular Controls on Kaolinite Surface Charge. J. Colloid Interface Sci. 1996, $183,356-364$. [CrossRef] [PubMed]

24. Zhou, Z.; Gunter, W.D. The Nature of the Surface Charge of Kaolinite. Clays Clay Miner. 1992, 4, 365-368. [CrossRef]

25. Gupta, V.; Miller, J.D. Surface Force Measurements at the Basal Planes of Ordered Kaolinite Particles. J. Colloid Interface Sci. 2010, 344, 362-371. [CrossRef]

26. IUSS Working Group. WRB World Reference Base for Soil Resources 2014. In International Soil Classification System for Naming Soils and Creating Legends for Soil Maps; FAO: Rome, Italy, 2014.

27. Forsyth, W.G. Studies on the More Soluble Complexes of Soil Organic Matter; a Method of Fractionation. Biochem. J. 1947, 41, 176-181. [CrossRef]

28. Isolation of IHSS Samples. Available online: https://humic-substances.org/isolation-of-ihss-samples/ (accessed on 5 November 2021).

29. Gran, G.; Dahlenborg, H.; Laurell, S.; Rottenberg, M. Determination of the Equivalent Point in Potentiometric Titrations. Acta Chem. Scand. 1950, 4, 559-577. [CrossRef]

30. Tolpeshta, I.I.; Sokolova, T.A.; Bonifacio, E.; Falsone, G. Pedogenic Chlorites in Podzolic Soils with Different Intensities of Hydromorphism: Origin, Properties, and Conditions of Their Formation. Eurasian Soil Sci. 2010, 43, 777-787. [CrossRef]

31. Karavanova, E.I.; Belyanina, L.A.; Stepanov, A.A. Water-Soluble Organic Matter and Soil Solution Acidity in the Main Soil Types of the Central Forest State Biosphere Reserve. Eurasian Soil Sci. 2007, 40, 493-504. [CrossRef]

32. Bokut, S.V.; Gerasimovich, N.V.; Milutin, A.A. Molecular Biology. In Molecular Mechanisms of Storage, Reproduction and Realization of Genetic Information; Higher School Publishing House: Minsk, Belarus, 2005.

33. Miyahara, M.; Vinu, A.; Ariga, K. Adsorption Myoglobin over Mesoporous Silica Molecular Sieves: Pore Size Effect and Pore-Filling Model. Mater. Sci. Eng. C 2007, 27, 232-236. [CrossRef]

34. Lammers, L.N.; Bourg, I.C.; Okumura, M.; Kolluri, K.; Sposito, G.; Machida, M. Molecular Dynamics Simulations of Cesium Adsorption on Illite Nanoparticles. J. Colloid Interface Sci. 2017, 490, 608-620. [CrossRef]

35. Appel, C.; Ma, L.Q.; Rhue, R.D.; Kennelley, E. Point of Zero Charge Determination in Soils and Minerals via Traditional Methods and Detection of Electroacoustic Mobility. Geoderma 2003, 113, 77-93. [CrossRef]

36. Kriaa, A.; Hamdi, N.; Srasra, E. Determination of Point of Zero Charge of Tunisian Kaolinites by Potentiometric and Mass Titration Methods. J. Chin. Chem. Soc. 2008, 55, 53-61. [CrossRef]

37. Kriaa, A.; Hamdi, N.; Srasra, E. Surface Properties and Modeling Potentiometric Titration of Aqueous Illite Suspensions. Surf. Eng. Appl. Electrochem. 2008, 44, 217-229. [CrossRef]

38. Zhao, H.; Bhattacharjee, S.; Chow, R.; Wallace, D.; Masliyah, J.H.; Xu, Z. Probing Surface Charge Potentials of Clay Basal Planes and Edges by Direct Force Measurements. Langmuir 2008, 24, 12899-12910. [CrossRef]

39. Huertas, F.J.; Chou, L.; Wollast, R. Mechanism of Kaolinite Dissolution at Room Temperature and Pressure: Part 1. Surface Speciation. Geochim. Cosmochim. Acta 1998, 62, 417-431. [CrossRef]

40. Liu, X.; Lu, X.; Sprik, M.; Cheng, J.; Meijer, E.J.; Wang, R. Acidity of Edge Surface Sites of Montmorillonite and Kaolinite. Geochim. Cosmochim. Acta 2013, 117, 180-190. [CrossRef]

41. Liu, Y.; Alessi, D.S.; Flynn, S.L.; Alam, M.S.; Hao, W.; Gingras, M.; Zhao, H.; Konhauser, K.O. Acid-Base Properties of Kaolinite, Montmorillonite and Illite at Marine Ionic Strength. Chem. Geol. 2018, 483, 191-200. [CrossRef]

42. Lee, S.S.; Fenter, P.; Park, C.; Nagy, K.L. Fulvic Acid Sorption on Muscovite Mica as a Function of PH and Time Using in Situ X-Ray Reflectivity. Langmuir 2008, 24, 7817-7829. [CrossRef] 